\title{
Estimation of solids and biodegraded metabolites in the raw and processed slurry of the two-phase Nisargruna biogas plant
}

\author{
Shubhada Nayak ${ }^{1 *}$, Sharad Kale ${ }^{2}$ \\ ${ }^{1}$ Department of Microbiology, Rayat Shikshan Sanstha's Karmaveer Bhaurao Patil College, Vashi, India. \\ ${ }^{2}$ Nuclear Agricultural Biotechnology Division, Bhabha Atomic Research Center, Trombay, India.
}

\begin{tabular}{l}
\hline ARTICLE INFO \\
\hline Article history: \\
Received on: February 23, 2021 \\
Accepted on: April 14, 2021 \\
Available online: November 10, 2021 \\
\hline
\end{tabular}

Key words:

Raw slurry, predigested slurry, Nisargruna biogas plant, digestate, bioenergy, solid waste management

\begin{abstract}
The use of the Nisargruna biogas plant is an efficient approach for solid waste management (SWM) with the simultaneous production of digestate and bioenergy. Monitoring of total solids and biodegraded metabolites of carbohydrates, proteins, and fats at different stages of digestion can provide comprehensive information about the efficiency of biogas plants. The current study was carried out to characterize the generation of solids and degraded biomolecules in the raw, predigested, and digestate (completely digested) slurry during the different stages of the two-phase Nisargruna biogas plant. It was conducted based on standard gravimetric techniques and biochemical assays. Our results indicated a significant reduction in total solids (40\%-45\%), carbohydrates $(60 \%-65 \%)$, proteins $(40 \%-45 \%)$, lipids (15\%-20\%), sugars, and free amino acids $(65 \%-70 \%)$ in the predigested slurry, as compared to the raw slurry. In addition, only formic acid $(2-2.5 \mu \mathrm{l} / \mathrm{ml})$ was detected in the raw slurry, whereas a significant amount of acetic acid $(25-30 \mu \mathrm{l} / \mathrm{ml})$ and small quantity of butyric acid (1 $\mu \mathrm{l} / \mathrm{ml}$ ) was detected in the predigested slurry. Furthermore, the digestate slurry showed the absence of volatile fatty acids indicating that they were efficiently utilized for methane formation in the main digester. The specific gravity and oxygen consumption rate in the predigester was estimated to be 1.0190 and $11.22 \mathrm{mg} / \mathrm{l} / \mathrm{minute}$, respectively. Lastly, the recyclable water obtained after dewatering the digestate slurry showed the absence of coliforms and a biological oxygen demand of $100 \mathrm{ppm}$, suggesting its suitability for disposal in the sewerage system. Based on the above chemical analysis of raw and processed slurry, the Nisargruna biogas plant thus proves to be highly efficient for SWM.
\end{abstract}

\section{INTRODUCTION}

The biochemically rich resources offered by plants and the ecosystem allow the maintenance of sustainability in nature. The key practice of recycling organic matter is essential for this process. Any imbalance in the above-mentioned practice may result in the disruption of several natural and interlinked elemental cycles that occur continuously, and hence have a negative impact on the environment. Currently, we are facing problems associated with the growing urban population that contributes immensely to the solid wastes produced globally [1]. Moreover, the inappropriate disposal of organic wastes severely challenges the

\section{*Corresponding Author}

Shubhada Nayak, Department of Microbiology, Rayat Shikshan Sanstha's Karmaveer Bhaurao Patil College, Vashi, India. E-mail:shubhadanayak@kbpcollegevashi.edu.in health of humans and animals. It also affects the soil microflora in close proximity to the waste disposal grounds, leading to the production of obnoxious odors or undesirable metabolic products that contribute to environmental risk factors. Hence, a proper solid waste management (SWM) system is crucial to avoid any unwanted harm to the environment and maintain sustainability on our planet [2].

The increasing population and rapid urban development in India have, in turn, increased the amount of disposed solid waste by several folds. Until 1947, the Indian cities generated up to 6 million tons of solid wastes annually. This figure increased to 48 million tons in 1997 and has been increasing ever since with an annual growth rate of $4.25 \%$. Currently, India produces over 62 million tons of solid wastes annually, and by 2047 it is expected to reach 300 million tons $[2,3]$. In spite of the radical measures undertaken for SWM, it remains a major problem requiring social, 
economic, technological, political, and administrative dimensions for effective solutions.The SWM generally involves thermal or chemical processes of waste disposal, like incineration and pyrolysis, or landfills. Less commonly, yet increasingly, the use of biological waste management techniques, like composting and biomethanation, has been implemented by municipal corporations in various cities of India [4]. One interesting approach in this attempt is the development of the Nisargruna biogas technology by the Bhabha Atomic Research Center, Mumbai, with a vision to treat organic wastes in order to return the elements to nature in acceptable forms. This technology combines the advancement in methods of biological treatment of wastes with biogas production technology to provide a productive and environment friendly approach of SWM. Currently, over 300 Nisargruna biogas plants of processing capacities ranging from 1 ton/day to 5 tons/day are successfully running in different parts of India [5].

In the Nisargruna biogas plant, the solid wastes are processed in two steps. The first step of hydrolysis and acidification is carried out in the aerobic predigester, which is divided into two compartments separated by a baffle wall in the center. The raw slurry is first collected in the predigester 1 and after initial decomposition and acquiring a flowing consistency, it moves to predigester 2. During the processing in this stage, the temperature is maintained between $40^{\circ} \mathrm{C}$ to $45^{\circ} \mathrm{C}$ to promote the degradation of waste material into their soluble monomeric components by extracellular enzymes produced by bacteria naturally introduced in the digester. The moderately high temperature further facilitates the conversion of degraded compounds into short-chain fatty acids, alcohols, $\mathrm{CO}_{2}$, and $\mathrm{H}_{2}$ by fermentative bacteria. After $72-96$ hours, the $\mathrm{pH}$ of the slurry falls below four. This slurry passes into the anaerobic digester where step two of the degradation process takes place in the absence of oxygen. The output of the process is a methane-rich biogas (methane, $80 \%$ and $\mathrm{CO}_{2}, 20 \%$ ) and a chemically stabilized digestate. The two steps combining aerobic and anaerobic degradation mechanisms allow complete breakdown of waste material in 18-20 days when compared to 30-40 days required in solely anaerobic digesters. In addition, the digestate acts as an excellent biofertilizer and the liquid obtained on dewatering is recycled into the biogas plant for mixing of the raw waste [6].

In the literature, several approaches of pretreatment of organic wastes have been reported previously to enhance the output of the bio-methanation process. In our study, the aerobic pretreatment stage was introduced based on the hypothesis that aerobic hydrolysis of organic wastes is much faster compared to that occurring in strict anaerobic digesters. Hence, it will accelerate the bio-methanation process without additional energy input. On following a similar approach of aerobic pretreatment of organic wastes (for hydrolysis), over $200 \%$ increase in methane production has been reported in the presence of mining residues [7]. In another approach, the anaerobic digestion was followed by the aerobic hydrolysis steps for effective reduction of solid content and removal of nitrogen fractions in the sludge [8]. A faster alternative to aerobic pretreatment is thermal hydrolysis of organic compounds. However, this process significantly increases the production cost in small-scale set-ups. On the other hand, the full-scale plants and continuous thermal hydrolysis can result in economic benefits $[9,10]$. Among other strategies undertaken by researchers for significant improvement in biogas production from solid wastes, the co-digestion of organic fraction of municipal wastes and animal/agro-wastes has demonstrated a stable outcome [11-13]. Small-scale and mobile biogas systems have also been commercialized in Central Vietnam and Kenya, respectively $[14,15]$, for effective SWM and simultaneous biogas production. However, these results were based on the anaerobic digestion process exclusively.

The current study was carried out with an objective to characterize organic wastes in raw and processed slurry for their chemical composition and hence analyze the steps in the degradation of wastes in the two-phase Nisargruna biogas plant.

\section{MATERIALS AND METHODS2.1. NISARGRUNA BIOGAS PLANT SET-UP AND COLLECTION OF SAMPLE}

The Nisargruna biogas plant was set up using $1,000 \mathrm{~kg}$ of raw material consisting of kitchen waste. It was homogenized in a mechanical mixer with the addition of hot water to obtain a slurry. The homogenization helps in faster degradation and the addition of hot water kills pathogenic organisms, if any. The raw slurry was then digested in the predigester tank with continuous aeration for 4 days. After digestion for 4 days, the predigested slurry was collected from the tank. The study was carried out for a week and samples were collected from homogenizers and predigesters, in sterile bottles every day. On complete digestion of wastes, the digestate samples were also collected similarly and processed. Also, the digestate was dewatered and the liquid thus obtained (recyclable water) was also analyzed for its biological oxygen demand (BOD) and microbial load. An outline of the Nisargruna process is shown in Figure 1.

\subsection{Preparation of the Sample}

Freshly withdrawn samples (200 g) were processed immediately in the laboratory by centrifuging at $10,000 \mathrm{rpm}$ for 10 minutes at $10^{\circ} \mathrm{C}$. The supernatant was collected in a clean flask and weighed. It was used for the estimation of volatile fatty acids, free amino acids, and sugars. The settled sediment was weighed and used for the estimation of total solids, volatile solids, and fixed solids. The sediment was also used for the biochemical analysis of proteins, carbohydrates, and lipids.

\subsection{Estimation of Total, Volatile, and Fixed Solids}

The solids in the raw slurry and processed slurry were estimated using the gravimetric technique. For this purpose, a clean evaporation dish was ignited at $55^{\circ} \mathrm{C}$ for 1 hour in a muffle furnace and stored in a desiccator for cooling, until the analysis was carried out. The dish was weighed just before use. For analysis of solids, $25 \mathrm{~g}$ of the slurry sample was placed in the evaporating dish and weighed. The sample was then evaporated to dryness on a water bath and then dried at $105^{\circ} \mathrm{C}$ for 1 hour. The sample was cooled in a desiccator and weighed again. It was then transferred to a cool muffle furnace, and the furnace was heated to $55^{\circ} \mathrm{C}$ and ignited for 1 hour. The sample was cooled in a desiccator and then weighed again. The solids in the raw and processed slurry were calculated using the following formulas [16-18]: 


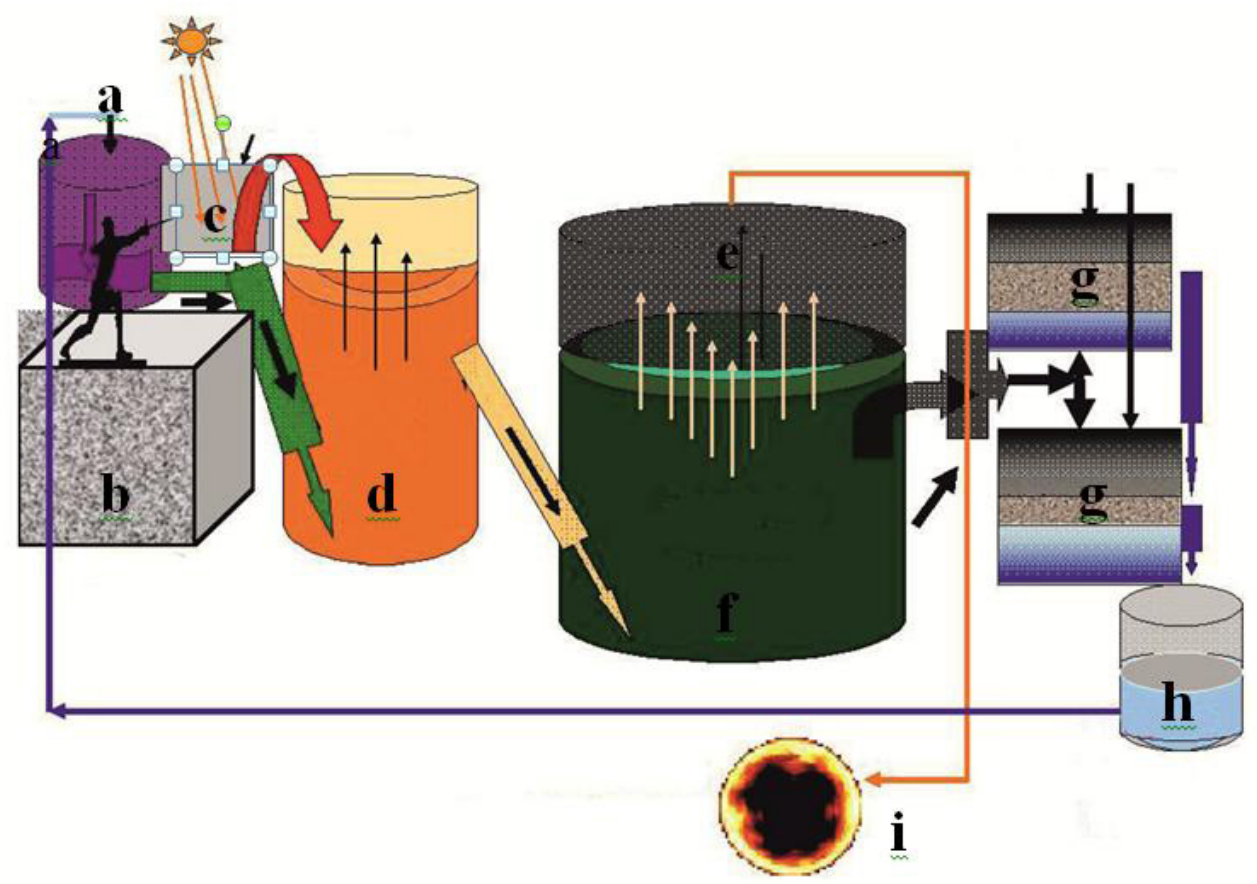

Figure 1: Outline of Nisargruna - components and technology. (a) Mixer, (b) platform (c) solar heater, (d) thermophilic aerobic digester, (e) methane holder, (f) anaerobic digester, $(\mathrm{g})$ manure pits, (h) recycle water tank, and (i) methane utilization.

$\%$ Total solids $=\frac{A-B}{C-B} \times 100 \ldots$ Eq (1)

$\%$ Volatile solids $=\frac{A-D}{A-B} \times 100 \ldots$ Eq (2)

$\%$ Fixed solids $=\frac{D-B}{A-B} \times 100 \ldots$ Eq (3)

where ' $A$ ' is the weight of the dried residue and dish, ' $B$ ' is the weight of the dish, ' $C$ ' is the weight of the wet sample and dish, and ' $D$ ' is the weight of the residue and dish after ignition.

\subsection{Estimation of Carbohydrates by Anthrone Method}

A $100 \mathrm{mg}$ sample of the above solids were mixed with $5 \mathrm{ml}$ of $2.5 \mathrm{~N} \mathrm{HCl}$ and kept in a boiling water bath for 3 hours. After cooling at room temperature, it was neutralized with $\mathrm{Na}_{2} \mathrm{CO}_{3}$ until the effervescence ceased. The volume was made up to 100 $\mathrm{ml}$ with water and the supernatant was used for the estimation of carbohydrates using the anthrone method. For this purpose, a standard graph of concentration of glucose (in $\mu \mathrm{g} / \mathrm{ml}$ ) versus absorbance (at $630 \mathrm{~nm}$ ) was plotted. The values of absorbance of test samples were extrapolated on a straight line and the concentration of carbohydrate in the sample was estimated from the standard graph.

\subsection{Estimation of Proteins by Biuret Method}

The solids ( $1 \mathrm{~g})$ obtained after centrifugation of the slurry were dewatered and mixed with $5 \mathrm{ml}$ of $3 \mathrm{~N} \mathrm{NaOH}$. The tubes were kept in a warm water bath for 5 minutes and used for the estimation of proteins by the biuret method. For this purpose, a standard graph of concentration of bovine serum albumin (in $\mathrm{mg} / \mathrm{ml}$ ) versus absorbance at $(530 \mathrm{~nm})$ was plotted. The values of absorbance of test samples were extrapolated on a straight line and the concentration of proteins in the sample was estimated from the standard graph.

\subsection{Estimation of Lipids by Using Soxhlet Extraction Method}

Ten grams of the dried sample was packed in Whatman number 1 filter paper and fitted into the connector of a Soxhlet assembly. An extraction flask was weighed and the lipids were extracted in a Soxhlet apparatus using acetone as the solvent at a rate of 20 cycles/hours for 8 hours. The solvent from the extraction flask was distilled by placing the flask in a water bath at $70^{\circ} \mathrm{C}$ for $15-20$ minutes. The flask was then cooled for 30 minutes in a desiccator and weighed and the lipids were estimated using the following formula:

Lipids $(\%)=\frac{B-A}{C} \times 100$

where ' $A$ ' is the weight of the empty extraction flask, ' $B$ ' is the weight of the flask with residue, and ' $C$ ' is the weight of the sample.

\subsection{Estimation of Total Free Amino Acids by Ninhydrin Method}

Raw slurry and predigested slurry were centrifuged and free amino acids in the supernatant were estimated by the ninhydrin method. For this purpose, various dilutions of standard stock solution of leucine were prepared and treated with ninhydrin reagent. A standard graph of concentration of leucine (in $\mu \mathrm{g}$ / 
$\mathrm{ml})$ versus absorbance at $(570 \mathrm{~nm})$ was plotted. The values of absorbance of test samples were extrapolated on a straight line and the concentration of free amino acids in the sample was estimated from the standard graph.

\subsection{Measurement of Volatile Fatty Acids by Gas Chromatography}

Volatile fatty acids are water-soluble fatty acids with up to six carbon atoms that can be distilled at atmospheric pressure. These volatile acids can be removed from an aqueous solution by distillation, despite their high boiling points due to their codistillation with water. The measurement of volatile fatty acids was carried out to determine the extent of digestion of organic material in the predigester. The quantity of volatile acids also indicates the amount of methane that will be produced in the main digester.

For the estimation of volatile fatty acids, $200 \mathrm{ml}$ of the sample was centrifuged at 5,000 rpm for 5 minutes. After this process, $100 \mathrm{ml}$ of the supernatant liquor was placed in a $500 \mathrm{ml}$ distillation flask. To this supernatant, $100 \mathrm{ml}$ of distilled water and $5 \mathrm{ml}$ of $\mathrm{H}_{2} \mathrm{SO}_{4}$ was added and mixed well. The flask was connected to a condenser and adapter tube and distilled at the rate of $5 \mathrm{ml} /$ minutes. The first $15 \mathrm{ml}$ of the distillate was discarded to eliminate errors due to $\mathrm{H}_{2} \mathrm{~S}$ and $\mathrm{CO}_{2}$ that are formed during distillation process. The volatile fatty acids separated by the distillation of slurry samples were quantified by gas chromatography using the Shimatzu GC-2014 model connected to the thermal conductivity detector (temperature $=200^{\circ} \mathrm{C}$ ). It was equipped with Porapac Q column $(3 \mathrm{~m}$ length and one quarter of an inch diameter) and a mesh size of 150-200. The column temperature was $150^{\circ} \mathrm{C}$ and the injector temperatures were $160^{\circ} \mathrm{C}$ (for formic acid and acetic acid analysis) and $180^{\circ} \mathrm{C}$ (for butyric acid and propionic acid analysis). Helium was used as a carrier gas. A sample volume of $500 \mu \mathrm{l}$ was injected to obtain a chromatogram. The standard calibration curve was prepared by injecting standard $1 \%$ acetic acid, formic acid, propionic acid, and butyric acid.

\subsection{Estimation of Biochemical Oxygen Demand of Recyclable Water}

The BOD of recyclable water was estimated to determine its suitability for direct disposal. For the estimation of BOD, the sample was diluted suitably (1:50 and 1:100) with aerated water and filled in $250 \mathrm{ml}$ BOD bottles. Four such bottles were prepared and labeled as $B_{I}, B_{F}, S_{I}$, and $S_{F}$, where $B_{I}$ and $B_{F}$ were filled with aerated water and $S_{I}$ and $S_{F}$ with diluted sample. The bottles $B_{F}$ and $\mathrm{S}_{\mathrm{F}}$ were stoppered tightly and incubated at $20^{\circ} \mathrm{C}$ for 5 days. Initial dissolved oxygen content in bottles $\mathrm{B}_{\mathrm{I}}$ and $\mathrm{S}_{\mathrm{I}}$ was measured immediately, and final dissolved oxygen content in bottles $\mathrm{B}_{\mathrm{F}}$ and $\mathrm{S}_{\mathrm{F}}$ was measured at the end of 5 days incubation.

To determine the dissolved oxygen content, $2 \mathrm{ml}$ of $\mathrm{MnSO}_{4}$ solution was added to the bottle, followed by the addition of $2 \mathrm{ml}$ of alkali azide solution. The contents were mixed by inverting the bottle few times. The resulting yellowish precipitate was allowed to settle for few minutes and then $2 \mathrm{ml}$ of concentrated $\mathrm{H}_{2} \mathrm{SO}_{4}$ was added. The bottle was inverted again few times until the precipitate was dissolved completely. The samples $(100 \mathrm{ml})$ were then titrated with $0.025 \mathrm{~N} \mathrm{Na}_{2} \mathrm{~S}_{2} \mathrm{O}_{3}$ solution till end point (pale yellow color) was observed. Few drops of starch indicator were added and the titration was continued till the first disappearance of the blue color. BOD was calculated using the following formula [19]:

$\operatorname{BOD}(\mathrm{mg} /)=\frac{\left(S_{i}-S_{F}\right)-\left(B_{i}-B_{F}\right)}{V} N 8 \times 1000 \mathrm{DF}$

where ' $B_{I}$ ' is the blank initial reading, ' $B_{F}$ ' is the blank final reading, ' $S_{I}$ ' is the sample initial reading, ' $S_{F}$ ' is the sample final reading, ' $N$ ' is normality of $\mathrm{Na}_{2} \mathrm{~S}_{2} \mathrm{O}_{3}$, ' $\mathrm{DF}$ ' is dilution factor, and ' $V$ ' is the volume of the sample taken for titration.

\subsection{Enumeration of Microflora in Recyclable Water}

The recyclable water $(10 \mathrm{ml})$ was mixed with $90 \mathrm{ml}$ of sterile saline, and serially diluted up to $10^{-6}$ dilutions. For enumeration of bacteria and fungi, $0.1 \mathrm{ml}$ of the last three dilutions were spread on sterile nutrient agar and rose bengal potato dextrose agar plates, respectively. The isolation was carried out in triplicates and the plates were incubated at $45^{\circ} \mathrm{C}$ for $24-48$ hours. The coliforms and pseudomonads in recyclable water were isolated, using undiluted sample, on MacConkey's agar and cetrimide agar plates, respectively, and incubated at $37^{\circ} \mathrm{C}$ for $24-48$ hours. After incubation, colonies were counted and colony-forming units per $\mathrm{ml}(\mathrm{CFU} / \mathrm{ml})$ were estimated.

\subsection{Estimation of Specific Gravity of Predigester Slurry}

Specific gravity was determined by comparing the mass of a known volume of a homogenous predigester slurry sample at a specific temperature to the mass of the same volume of distilled water at $4^{\circ} \mathrm{C}$. To estimate the specific gravity, the temperature (T) of the sample and weight (W) of the empty container were recorded. The container was filled to the mark with the sample and weighed (S) again. The empty container was then filled to the mark with water and its weight $(\mathrm{R})$ was recorded. The specific gravity was recorded using the following formula:

Specific gravity $\left(4^{\circ} \mathrm{C}\right)=\frac{S-W}{R-W} \times F$

where $F\left(0.9903\right.$ for $\left.45^{\circ} \mathrm{C}\right)$ is the correction value that varies with temperature.

\subsection{Estimation of Oxygen Consumption Rate}

The predigester of the Nisargruna biogas plant is an aerobic digester which requires appropriate aeration to support the growth and metabolism of bacteria. Hence, the rate of oxygen consumption was determined to decide the aeration rate in the predigester. For this purpose, the oxygen probe and the meter were calibrated according to the manufacturer's specifications. Freshly collected sample $(100 \mathrm{ml})$ was adjusted to $45^{\circ} \mathrm{C}$ and processed immediately. The temperature was maintained during analysis and dissolved oxygen of the sample was increased by bubbling air through it. The BOD bottle containing magnetic stirring bar was filled with the sample up to the brim. The oxygen-sensitive probe was immediately inserted into the sample. During this process, enough volume of the sample was displaced with a probe to fill the 
flared top of bottle and isolate its contents from the atmosphere. A magnetic stirrer was activated at $300 \mathrm{rpm}$. After the meter reading was stabilized, initial dissolved oxygen was recorded and a timer was set. Readings were recorded every second until the dissolved oxygen became limiting. A graph of dissolved oxygen $(\mathrm{mg} / \mathrm{l})$ (ppm) versus time (sec) was plotted and the oxygen consumption rate was calculated from the slope in $\mathrm{mg} / \mathrm{l} / \mathrm{minute}$.

As the readings are sensitive to temperature and time lag between sample collection and test initiation, multiple readings were taken and their average was considered for final estimation.

\section{RESULTS AND DISCUSSION}

\subsection{Estimation of Solids and Degraded Compounds}

Table 1 represents the total solids, proteins, carbohydrates, and lipids estimated from the raw and predigested slurry samples over 6 days. Table 2 indicates the amount of total volatile and fixed solids, and degradation indicators of carbohydrates (sugars), proteins (amino acids), and lipids (volatile acids) in the raw, predigested, and digestate slurry samples.

In the present study, $60 \%-65 \%$ reduction in carbohydrate content, $40 \%-45 \%$ reduction in protein content, and $15 \%-20 \%$ reduction in lipid content of waste were observed (Table 1). Similarly, 65-70\% reduction in sugars and free amino acids was also observed (Table 2). These observations are clear indications of the biodegradation of organic wastes. The variation in degradation patterns can be correlated to the degree of complexity of the biomolecules and enzymatic abilities of the aerobic species involved in the bioprocess. The increasing concentration of volatile fatty acids is also a sign of the degradation of biomolecules. A detailed analysis of the concentrations of different volatile fatty acids like formic acid, acetic acid, propionic acid, and butyric acid was carried out by gas chromatography. Our results indicated the presence of only formic acid $(2-2.5 \mu \mathrm{l} / \mathrm{ml})$ in the raw slurry. On digestion for 96 hours under aerobic conditions, the concentration of acetic acid was $25-30 \mu \mathrm{l} / \mathrm{ml}$. A very small quantity of butyric acid $(1 \mu \mathrm{l} /$ $\mathrm{ml}$ ) was also found in the predigested slurry. The digestate slurry showed the absence of any volatile fatty acids, indicating that they were efficiently used for methane formation in the main digester. These observations were also highly significant since it indicated that the aerobic degradation and fermentation of waste lead to the production of volatile fatty acids that are utilized by acetogenic bacteria to acetic acid, which in turn is used by methanogenic organisms to generate methane during the second stage which is anaerobic.

Since acetic acid is produced as a major acid in the predigester, the involvement of acetogenic bacteria is avoided by allowing this slurry to pass into the anaerobic chamber of the Nisargruna plant to initiate methanogenesis. Ideally, equal amounts of methane and $\mathrm{CO}_{2}$ are produced on anaerobic digestion of sugars, starch, and cellulose. On the other hand, although the retention period is increased significantly, a much greater quantity of methane can be produced on complete anaerobic digestion of proteins and fats when compared to carbohydrates [10]. As observed in our study, significant amounts of proteins and lipids are metabolized on aerobic pretreatment. This step may enhance the hydrolysis of biochemical compounds and thus provide ready raw materials for methanogenesis, thus reducing the retention time.

\subsection{Total Solids, Volatile Solids, and Fixed Solids in Raw and Processed Slurry}

Total and volatile solids are indicators of organic matter content in the waste [20]. They were estimated to be $90 \%-94 \%$ in the

Table 1: Chemical analysis of raw and predigested slurry.

\begin{tabular}{|c|c|c|c|c|c|c|c|c|}
\hline \multirow[t]{2}{*}{ Day } & \multicolumn{2}{|c|}{ TS “\% } & \multicolumn{2}{|c|}{ Lipids ' $\%$ of TS' } & \multicolumn{2}{|c|}{ Proteins ' $\%$ of TS' } & \multicolumn{2}{|c|}{ Carbohydrates ' $\%$ of TS' } \\
\hline & Raw & PD & Raw & PD & Raw & PD & Raw & PD \\
\hline 1 & 23.48 & 13.73 & 5.33 & 4.50 & 6.2 & 3.9 & 9.5 & 3.6 \\
\hline 2 & 23.35 & 13.34 & 6.0 & 4.41 & 6.6 & 3.24 & 8.4 & 4.0 \\
\hline 3 & 24.76 & 14.82 & 7.5 & 6.1 & 6.1 & 4.0 & 9.2 & 4.4 \\
\hline 4 & 24.11 & 13.0 & 6.9 & 5.5 & 7.1 & 3.2 & 8.6 & 3.8 \\
\hline 5 & 25.28 & 14.82 & 8.2 & 5.8 & 7.2 & 4.3 & 9.0 & 4.1 \\
\hline 6 & 24.47 & 13.87 & 7.10 & 5.6 & 7.0 & 3.8 & 8.5 & 3.9 \\
\hline Average & 24.24 & 13.93 & 6.83 & 5.3183 & 6.7 & 3.74 & 8.8666 & 3.9666 \\
\hline Std. deviation & 0.7471 & 0.7537 & 1.0424 & 0.7000 & 0.4732 & 0.4363 & 0.4366 & 0.2732 \\
\hline Std. error & 0.3051 & 0.3077 & 0.4256 & 0.2858 & 0.1932 & 0.1781 & 0.1782 & 0.1115 \\
\hline
\end{tabular}

Raw $=$ Raw slurry; $\mathrm{PD}=$ Predigested slurry $; \mathrm{TS}=$ Total solids.

Table 2: Estimation of degraded components in raw and predigested slurry.

\begin{tabular}{|c|c|c|c|c|c|c|}
\hline Sample & $\begin{array}{c}\text { Total solids } \\
6 \%\end{array}$ & $\begin{array}{l}\text { Total volatile } \\
\text { solids '\%? }\end{array}$ & $\begin{array}{l}\text { Total fixed } \\
\text { solids '\%? }\end{array}$ & $\begin{array}{c}\text { Free amino acids } \\
\text { 'mg \%' }\end{array}$ & $\begin{array}{l}\text { Sugars } \\
\text { 'mg \%' }\end{array}$ & Acids ' $\mu \mathrm{l} / \mathrm{ml}$ ' \\
\hline Raw slurry & 24.24 & 87.23 & 12.77 & 30.5 & 53.89 & Formic acid (2.51) \\
\hline Predigested slurry & 13.93 & 94.04 & 5.96 & 9.9 & 15.29 & $\begin{array}{c}\text { Acetic acid (28) } \\
\text { Butyric acid }(0.785)\end{array}$ \\
\hline Digestate slurry & 16. 33 & 71.76 & 28.23 & - & - & - \\
\hline
\end{tabular}


predigester, thus indicating the organic nature of the waste. In the Nisargruna biogas plant, the process of predigestion takes place for 72-96 hours. During this time, the total solids in raw waste were estimated to be $23 \%-25 \%$. This was rapidly degraded and only $13 \%-14 \%$ remained at the end of the predigestion stage. Thus, a significant reduction in total solids $(40 \%-45 \%)$ was observed in the current study. This observation is beneficial for the Nisargruna system since the reduction in total solids, in turn, reduces the scum formation and increases the free flow of the slurry from the predigester to the main digester. Moreover, higher concentrations of total solids negatively influence the biogas production [21]. This is because the total solids represent the concentrated metabolites which are often toxic to the methanogenic bacteria. Also, the increasing concentration of total solids leads to the accumulation of volatile fatty acids and $\mathrm{pH}$ shift. This supports heterogenic bacterial communities and increases the competition for strict methanogens $[22,23]$. Thus, the reduction in total solids plays a major role in improving the efficiency of the biogas plants. This observation has also been supported by other researchers in previous studies [24-26].

In addition to the significant reduction in total solids, the concentration of volatile solids was found to increase by $7.24 \%$ and the fixed solids decreased by $53.32 \%$ after the predigestion of raw slurry. Together, these observations suggest the metabolism of wastes into organic compounds that are readily converted into organic acids (i.e., substrates required for methanogenesis). The significant amount of volatile acids detected in the present study, after predigestion stage (Table 2), further supports these interpretations. Thus, it is evident that the predigestion stage complements the initiation of methanogenesis and its introduction in the Nisargruna plant leading to a significant improvement in biogas production.

Unlike other anaerobic digesters that show a processing time of over 30-60 days [27-29], the Nisargruna biogas plant serves the same purpose within 20 days. This can be attributed to the above-mentioned observations of rapid waste degradation during the pretreatment under aerobic conditions. In turn, these observations can be associated with the difference in microflora observed during the two phases of the Nisargruna plant.

\subsection{Analysis of Recyclable Water}

The BOD of recyclable water was estimated to be $100 \mathrm{ppm}$. The microbiological analysis of recyclable water indicated the presence of $18.96 \times 10^{4} \mathrm{CFU} / \mathrm{ml}$ bacteria and the absence of fungi and coliforms. Pseudomonas sp. enumerated on cetrimide agar was $50 \mathrm{CFU} / \mathrm{ml}$. In general, the BOD of household and industrial wastewater was recorded between 700 and 1,500 ppm. On treatment of wastewaters, a BOD range below 300 ppm was considered acceptable for its discharge in to sewer systems [30]. In the Nisargruna biogas plant, this water is simply recycled back into the predigester for proper mixing of raw slurry. The recyclable water obtained on dewatering the digestate contains various soluble nutrients and hence can prove to be an excellent source of fertilizers for plants [31]. It can also be used for the purpose of irrigation after suitable dilution [32]. The absence of coliforms and low BOD in our study suggests its suitability for both these purposes. A similar study reported over 90\% BOD removal efficiency of biogas plant fed with dairy wastewater and glycerol [33]. Other studies have reported $34.6 \%$ and $90 \%$ reductions in the BOD of sludge produced from anaerobic digesters used for treatment of municipal/industrial and household/personal products industrial wastewaters, respectively [34-35].

\subsection{Estimation of Specific Gravity and Oxygen Consumption Rate of Predigester Slurry}

The predigester of the Nisargruna biogas plant functions at $45^{\circ} \mathrm{C}$ under aerobic conditions. Hence, the specific gravity was calculated at this temperature. Aeration is a critical parameter for appropriate hydrolysis and fermentation of waste materials. At the same time, this process is expensive. Hence, it is crucial to determine the oxygen consumption rate of the bacteria. The specific gravity of the predigester slurry in the current study was estimated to by 1.0190 and the oxygen consumption rate was calculated as $11.22 \mathrm{mg} / \mathrm{l} / \mathrm{minute}$ (Fig. 2).

The raw slurry usually comprises fairly coarse organic particles with a specific gravity (density) significantly greater than water. They have an unpleasant odor due to the presence of over $60 \%-80 \%$ volatile solids (organic). As the slurry is treated biologically, the specific gravity reduces to match the specific gravity of water. At this point, the effluent contains fewer solids and has a flowing consistency. Microorganisms in the slurry use oxygen as they consume organic matter. The level of microbial activity is indicated by the microorganisms' oxygen uptake rate. High oxygen uptake rates indicate high microbial activity and high organic matter content, whereas low oxygen uptake rates indicate low microbial activity and low organic matter content $[36,37]$. The oxygen consumption rate of a well-operated aerobic sludge digester is between 0.1 and $15 \mathrm{mg} / \mathrm{l} / \mathrm{minute}$ [38]. These parameters are crucial for evaluating the efficiency of a bioprocess.

\section{Oxygen consumption rate}

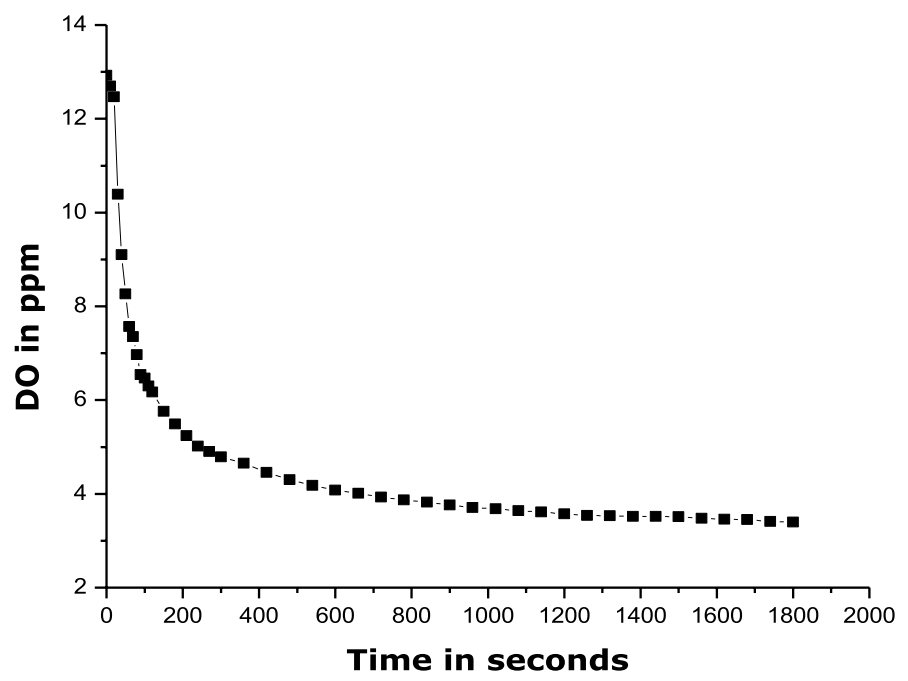

Figure 2: Oxygen consumption rate in the predigester during the aerobic digestion phase of the Nisargruna biogas plant 


\section{CONCLUSION}

Any biodegradable waste generally consists of three basic biomolecules: carbohydrates, proteins, and lipids in variable proportions. This holds true for kitchen waste too. In the predigester of the Nisargruna biogas plant, the raw waste is hydrolyzed and fermented in presence of air (by aerobic bacteria). The proteins, carbohydrates, and lipids are broken down to their respective monomers that are fermented to mixtures of volatile fatty acids like formic acid, acetic acid, propionic acid, and butyric acid along with liberation of $\mathrm{CO}_{2}$. The volatile acids produced remain in the aqueous phase. Thus, a reduction in the concentrations of carbohydrates, proteins, and lipids, and increase in the concentrations of volatile fatty acids are clear-cut indications of microbial degradation of the waste. When bio-waste is degraded only under anaerobic conditions, all the steps leading to methane formation, i.e., hydrolysis, fermentation, acetogenesis, and methanogenesis, are carried out by consortium of anaerobic bacteria. Anaerobic hydrolysis is a slow process and hence a ratelimiting step. Due to partitioning of hydrolysis and fermentation under aerobic conditions and acetogenesis and methanogenesis under anaerobic conditions, the acidogenesis (hydrolysis and fermentation) is no longer a rate-limiting step. Thus, the entire degradation process occurs faster, and this ultimately reduces the retention time of the waste in the biogas plant. Thus, the use of this technology can evidently pave the way towards $\backslash$ a 'zero waste and zero effluent' management system that is eco-friendly in nature. Thus, the practical implementation of microbial metabolic activities for processing of wastes, using a two-step process in the Nisargruna biogas plant, is an attractive approach for efficient and faster SWM.

\section{AUTHOR CONTRIBUTIONS}

All authors made substantial contributions to conception and design, acquisition of data, or analysis and interpretation of data; took part in drafting the article or revising it critically for important intellectual content; agreed to submit to the current journal; gave final approval of the version to be published; and agree to be accountable for all aspects of the work. All the authors are eligible to be an author as per the international committee of medical journal editors (ICMJE) requirements/guidelines.

\section{FUNDING}

There is no funding to report.

\section{CONFLICTS OF INTEREST}

The authors report no financial or any other conflicts of interest in this work.

\section{ETHICAL APPROVALS}

This study does not involve experiments on animals or human subjects.

\section{REFERENCES}

1. Naveen BP, Sivapullaiah PV. Solid waste management: current scenario and challenges in Bengaluru, sustainable sewage sludge management and resource efficiency, Basak Kilic Taseli. IntechOpen, 2020. Available via https:/www.intechopen.com/books/sustainablesewage-sludge-management-and-resource-efficiency/solid-wastemanagement-current-scenario-and-challenges-in-bengaluru

2. Joshi R, Ahmed S. Status and challenges of municipal solid waste management in India: a review. Cogent Environ Sci 2016;2:1139434.

3. Swaminathan M. How can India's waste problem see a systemic change? Econ Polit Wkly 2018. Available via https://www.epw.in/ node/151565/pdf (Accessed 16 October 2020).

4. Patil BS, Agnes Anto C, Singh DN. Simulation of municipal solid waste degradation in aerobic and anaerobic bioreactor landfills. Waste Manag Res 2017;35:301-12.

5. Nayak S. Microbiological studies for characterization and process improvement in "Nisargruna" biogas plant. Ph.D Thesis submitted to the University of Mumbai, Mumbai, India, 2008.

6. Kale SP, Nayak SS. Nisargruna: a novel method for degradation of organic waste. 3rd International Conference on Environmental Science and Technology, Greenspoint Wyndham Hotel, Houston, TX, 2007.

7. Montalvo S, Vielma S, Borja R, Huiliñir C, Guerrero L. Increase in biogas production in anaerobic sludge digestion by combining aerobic hydrolysis and addition of metallic wastes. Renew Energy 2018;123:541-8.

8. Parawira W, Murto M, Zvauya R, Mattiason B. Anaerobic batch digestion of solid potato waste alone and in combination with sugar beet leaves. Renew Energy 2004;29:1811-23.

9. Pérez-Elvira SI, Fdz-Polanco F. Continuous thermal hydrolysis and anaerobic digestion of sludge. Energy integration study. Water Sci Technol 2012;65(10):1839-46.

10. Cano R, Nielfa A, Fdz-Polanco M. Thermal hydrolysis integration in the anaerobic digestion process of different solid wastes: energy and economic feasibility study. Bioresour Technol 2014;168:14-22.

11. Adebayo AO, Jekayinfa SO, Linke B. Effect of co-digestion on anaerobic digestion of pig slurry with maize cob at mesophilic temperature. J Nat Sci Res 2014;4:66-73.

12. Parra-Orobio BA, Torres-Lozada P, Marmolejo-Rebellón LF. Influence of the mixing ratio on the anaerobic co-digestion of municipal biowaste with domestic wastewater sludge on methane production. DYNA 2016;83:86-93.

13. Stan C, Collaguazo G, Streche C, Apostol T, Cocarta DM. Pilot-scale anaerobic co-digestion of the OFMSW: improving biogas production and startup. Sustainability 2018;10(6):1939.

14. Sovacool BK, Kryman M, Smith T. Scaling and commercializing mobile biogas systems in Kenya: a qualitative pilot study. Renew Energy 2015;76:115-25.

15. Roubík H, Mazancová J, Le Dinh P, Dinh Van D, Banout J. Biogas quality across small-scale biogas plants: a case of Central Vietnam. Energies 2018;11(7):1794.

16. Angelidaki I, Ellegaard L. Codigestion of manure and organic wastes in centralized biogas plants; status and future trends. Appl Biochem Biotechnol 2003;109(1-3):95-106.

17. Alvarez JM. Biomethanization of organic fraction of municipal solid waste. IWA Publishing, Clove Crescent, London, UK, 2002.

18. Alvarez JM, Mace S, Llabres L. Anaerobic digestion of organic solid wastes. An overview of research achievements and perspectives. Bioresour Technol 2000;74(3):16.

19. American Public Health Association, American Water Works Association, and Water Environment Federation. Standard methods for the examination of water and wastewater. American Public Health Association, Washington, DC, 2005.

20. Font X, Artola A, Sánchez A. Detection, composition and treatment of volatile organic compounds from waste treatment plants. Sensors (Basel) 2011;11(4):4043-59.

21. Karthikeyan O, Visvanathan C. Bio-energy recovery from high-solid organic substrates by dry anaerobic bio-conversion processes: a review. Rev Environ Sci Biotechnol 2013;12:257-84. 
22. Motte JC, Trably E, Escudié R, Hamelin J, Steyer JP, Bernet N, et al. Total solids content: a key parameter of metabolic pathways in dry anaerobic digestion. Biotechnol Biofuels 2013;6(1):164.

23. Li A, Chu Y, Wang X, Ren L, Yu J, Liu X, et al. A pyrosequencingbased metagenomic study of methane-producing microbial community in solid-state biogas reactor. Biotechnol Biofuels 2013;6:3.

24. Abbassi-Guendouz A, Brockmann D, Trably E, Dumas C, Delgenès JP, Steyer JP, et al. Total solids content drives high solid anaerobic digestion via mass transfer limitation. Bioresour Technol 2012;111:5561.

25. Staley BF, De Los Reyes FL, Barlaz M. Effect of spatial differences in microbial activity, $\mathrm{pH}$, and substrate levels on methanogenesis initiation in refuse. Appl Environ Microbiol 2011;77:2381-91.

26. Abbassi-Guendouz A, Trably E, Hamelin J, Dumas C, Steyer JP, Delgenès JP, et al. Microbial community signature of high-solid content methanogenic ecosystems. Bioresour Technol 2013;133:25662.

27. Cassie BL, Dileo MJ, Lee JA. Methane creation from anaerobic digestion. Worcester Polytechnic Institute Project Number: RWT1001; 2010. Available via https://web.wpi.edu/Pubs/E-project/ Available/E-project-042810-154622/unrestricted/DigestionIQP2.pdf. (Accessed 7 November 2020).

28. Shi XS, Dong JJ, Yu JH, Yin H, Hu SM, Huang SX, et al. Effect of hydraulic retention time on anaerobic digestion of wheat straw in the semicontinuous continuous stirred-tank reactors. Biomed Res Int 2017; 2017:2457805

29. Mes TZD, Stams AJM, Reith JH, Zeeman G. Methane production by anaerobic digestion of wastewater and solid wastes. In: Reith JH, Wijffels RH, Barten H (ed.). Bio-methane \& Bio-hydrogen: status and perspectives of biological methane and hydrogen production petten. Dutch Biological Hydrogen Foundation, The Hague, Netherlands, pp 58-102, 2003

30. Norton JF. Standard methods for the examination of water and sewage. 9th edition, American Public Health Association, Washington, DC, $\mathrm{p}$ 39, 1946.

31. Bernhard D, Werner F, Teodorita AS, Michael M, Bernd L. nutrient recovery by biogas digestate processing. Technical Brochure by IEA
Bioenergy. 2015. Available via http://task37.ieabioenergy.com/files/ daten-redaktion/download/Technical\%20Brochures/NUTRIENT RECOVERY_RZ_web1.pdf (Accessed 11 March 2021).

32. Fuchs W, Drosg B. Assessment of the state of the art of technologies for the processing of digestate residue from anaerobic digesters. Water Sci Technol 2013; 67(9):1984-93.

33. Chou YC, Su JJ. Biogas production by anaerobic co-digestion of dairy wastewater with the crude glycerol from slaughterhouse sludge cake transesterification. Animals (Basel) 2019;9(9):618.

34. Araujo DJ, Rocha SMS, Cammarota MC, Xavier AMF, Cardoso VL. Anaerobic treatment of wastewater from the household and personal products industry in a hybrid bioreactor. Braz J Chem Eng 2008; 25(3):443-51.

35. Gani KM, Ali M, Singh SO, Kazmi AA. Evaluation of treatment potential, biogas generation and sludge properties of an anaerobic claridigester. J Water Sanit Hyg Dev 2016; 6(1):23-31.

36. Telliard WA. Specific oxygen uptake rate in biosolids. U.S. Environmental Protection Agency EPA-821-R-01-014. 2001 Available via https://www.epa.gov/sites/production/files/2015-10/ documents/method_1683 draft 2001.pdf (Accessed 7 November 2020).

37. Moser B, Falkner D, Altmann R, Tomaro D, Bertolas N, Ohm S, et al Biological solids and sludges - handling, processing, and reuse study guide. 2016. Available via https://dnr.wi.gov/topic/opcert/documents/ StudyGuideBiosolids.pdf (Accessed 7 November 2020).

38. Rodriguez J, Ruiz G, Molina F, Roca E, Lema JM. A hydrogen-based variable-gain controller for anaerobic digestion processes. Water Sci Technol 2006;54(2):57-62.

How to cite this article:

Nayak S, Kale S. Estimation of solids and biodegraded metabolites in the raw and processed slurry of the twophase Nisargruna biogas plant. J Appl Biol Biotech 2021; 9(06):100-107. 